\author{
Jolanta Kurkiewicz \\ Cracow University of Economics \\ kurkiewj@uek.krakow.pl \\ Ewa Soja \\ Cracow University of Economics \\ sojae@uek.krakow.pl
IN THE CONTEXT OF THEIR LIVING
ARRANGEMENTS \\ INFORMAL SUPPORT FOR THE ELDERLY \\ IN SELECTED EUROPEAN COUNTRIES ${ }^{1}$
}

\title{
INTRODUCTION
}

Population ageing is a typical phenomenon of the demographic changes in the developed world. In Europe, where the proportion of older people is very high, it is a subject of special interest. The consequences of ageing are therefore an area of particular attention, inter alia in the context of the stability of the pension system, social welfare, healthcare and standard of living (Börsch-Supan 2003, Lee and Tuljapurkar 1997, Prskawetz et al. 2008, Soja and Stonawski 2012). Although demographic ageing relates directly to the elderly, it should also be considered as

\footnotetext{
${ }^{1}$ Publikacja została dofinansowana ze środków przyznanych Wydziałowi Zarządzania Uniwersytetu Ekonomicznego w Krakowie, w ramach dotacji na utrzymanie potencjału badawczego.

This paper uses data from SHARE wave 5 release 1.0.0, as of March 31st 2015 (DOI: 10.6103/ SHARE.w5.100) or SHARE wave 4 release 1.1.1, as of March 28th 2013 (DOI: 10.6103/SHARE. w4.111) or SHARE waves 1 and 2 release 2.6.0, as of November 29th 2013 (DOIs: 10.6103/SHARE. w1.260 and 10.6103/SHARE.w2.260) or SHARELIFE release 1.0.0, as of November 24th 2010 (DOI: 10.6103/SHARE.w3.100). The SHARE data collection has been primarily funded by the European Commission through the 5th Framework Programme (project QLK6-CT- 2001-00360 in the thematic programme Quality of Life), through the 6th Framework Programme (projects SHARE-I3, RIICT-2006-062193, COMPARE, CIT5- CT-2005-028857, and SHARELIFE, CIT4-CT-2006-028812) and through the 7th Framework Programme (SHARE-PREP, $N^{\circ} 211909$, SHARE-LEAP, $N^{\circ} 227822$ and SHARE M4, $\mathrm{N}^{\circ}$ 261982). Additional funding from the U.S. National Institute on Aging (U01 AG0974013S2, P01 AG005842, P01 AG08291, P30 AG12815, R21 AG025169, Y1-AG-4553-01, IAG BSR06-11 and OGHA 04-064) and the German Ministry of Education and Research as well as from various national sources is gratefully acknowledged (see www.share-project.org for a full list of funding institutions).
} 
a process affecting the entire population. It is a new approach which was proposed and adopted in MULTILINKS project (see Dykstra and Komter 2012).

The population surviving in a given period consists of earlier born generations being at different stages of life, with diverse experiences and different individual and family biographies. Demographic changes (primarily fertility and mortality decline) modify the relations between younger and older generations, both at the level of the family and society. The mortality decline results in the elongation of vertical linkages (Martin and Culter 1983, Bengtson et al. 1990, Uhlenberg 1993), whereas the decline of fertility contributes to a reduction in horizontal relations (Knipscheer 1992). The mortality decrease prolongs the period of living together by different generations in the role of partners, grandparents and great-grandparents (Puur et al. 2011). As regards people whose partnerships were dissolved and who do not establish another relationships, the mortality decline may mean a longer life without a partner (de Jong Gierveld et al. 2001). The consequences of the changes in the fertility result not only from the decline in its level. What is also significant here is delaying the decision of parenthood, which in turn contributes to an increase of the intervals between generations. As a result, the number of generations living at the same time may be reduced.

The members of the family (kin) network are linked with a special kind of relations. There are mutual obligations and responsibilities resulting in flows of support from older to younger generations and vice versa (informal support). The relationships are shaped by cultural, social and legal standards (Grotowska-Leder 2008, Saraceno and Keck 2008, Abramowska-Kmon 2011, Dykstra and Komter 2012, Dykstra et al. 2013).

The flows of the family support are considered within the structure of households of the elderly (living arrangements, co-residential arrangements). Elderly people living together with their children or other relatives is one of the family support types (Palloni 2001). The structure of households of the elderly is shaped by their biographies. By mid- $20^{\text {th }}$ century the histories of the subsequent generations were more similar than the histories of present generations, whose adult life was spent under the conditions of the Second Demographic Transition (Lesthaeghe 2010, van de Kaa 1987, 2004). What is of particular significance in this scope is the new models of partnerships (de Jong Gierveld et al. 2001). Apart from marriage we deal with cohabitation and relationships defined as living apart together (LAT). What results from the dissolution of one partnership and establishing new ones is a stepfamily. Consequently, the structures of households of the elderly become more diversified than ever before.

Considering the structure of the households in the context of the flows of the support one may distinguish: (1) households of only elderly people i.e. single elderly person living on his/her own or only an elderly couple and (2) households in which older people live together with their children, other relatives and non-relatives. The elderly living on their own expect, in most cases, the aid from outside the household. Most often this type of a household consists of women (widows) and people 
at an old age who have lost a partner and whose children have left the household. Generally, the number of such households increases, but the opposite tendency may be observed as well. It happens, for instance, in such countries as Austria, Germany and Italy. In these cases, the main reason is the mortality decline (reduction in the frequency of becoming a widow/widower) and the fact that children become independent at a later age. As regards Central and Eastern Europe, the period of staying in the household is extended for financial reasons and difficulties in purchasing a flat (see de Jong Gierveld et al. 2012). The population that demands a special attention in the context of the support is elderly people experiencing difficulties in everyday life (Chłoń-Domińczak 2014, Grundy 2001).

\section{PURPOSE AND SCOPE OF THE RESEARCH}

The main objective of this paper is to analyze the informal support for elderly people ${ }^{2}$ experiencing problems in everyday life connected with physical, mental or emotional fitness. The following hypotheses are formulated:

(1) the occurrence of problems in everyday life shapes living arrangements (type of the household) of the elderly,

(2) informal help from outside the household obtained by the older people experiencing problems in everyday life is determined by the type of the household and by social and demographic characteristics of the individuals receiving the support.

The scope of problems covers the so called limitations with activities of daily living (ADL) as well as limitations with instrumental activities of daily living (IADL) ${ }^{3}$. Informal support for the elderly refers to non-financial help received from outside of the household. The range of help includes personal care (e.g. dressing, bathing or showering, eating, getting in or out of bed, using the toilet), practical household help (e.g. with home repairs, gardening, transportation, shopping, household chores) and help with paperwork such as filling out forms, settling financial or legal matters ${ }^{4}$.

2 The selected population of older people is consistent with the solutions adopted in the SHARE project (Survey of Heath, Aging and Retirement in Europe). The investigated population includes people aged 50 and more (see http://www.share-project.org/home0.html, access 15.04.2014).

${ }^{3}$ Measurement of difficulties of everyday life has been adopted according to the recommendations defined in the SHARE project. The measures ALD and IADL cover the following limitations: dressing, including putting on shoes and socks; walking across a room; bathing or showering; eating, such as cutting up your food; getting in and out of bed; using the toilet, including getting up or down (ADL) and using a map to figure out how to get around in a strange place; preparing a hot meal; shopping for groceries; making telephone calls; taking medications; doing work around the house or garden; managing money, such as paying bills and keeping track of expenses (IADL) (see: SHARE - Release Guide 2.6.0, pp. 35, 2013; http://www.share-project.org/home0.html, access 15.04.2014). A similar scope of limitations of ADL and IADL measures has been applied in the work by United Nations 2005.

${ }^{4}$ Such an understanding of informal help is consistent with the solutions adopted in the SHARE project. The similar understanding of informal help has been also adopted in the work by Kalbarczyk and Nicińska 2009. 
Four types of households (living arrangements) are distinguished:

I. an elderly person living on his/her own,

II. only a couple (married couple/partners),

III. an elderly person without a partner, living with other people,

IV. a couple living with other people.

The analysis covers groups of countries chosen from the participants of SHARE project: post-transitional countries - the Czech Republic, Hungary Poland and Slovenia, and other Northern, Western and Southern European countries: Sweden, the Netherlands, France, German and Portugal. They represent not only geographical regions but also various demographic behaviors.

\section{DATA AND METHODS}

Empirical data comes from the SHARE project (Survey of Health Ageing and Retirement in Europe $)^{5}$. The logit models are applied in order to verify the research hypotheses. The general formula of the model is defined as follows ${ }^{6}$ :

$$
g(\boldsymbol{Y})=\boldsymbol{X} \boldsymbol{\beta}+\boldsymbol{\varepsilon}
$$

where: $\mathbf{Y}-(\mathrm{nx} 1)$ vector of a dependent variable, $\mathrm{g}-$ logit link function, $\mathbf{X}-(\mathrm{nxk})$ matrix of values of independent variables, $\boldsymbol{\beta}-(\mathrm{kx} 1)$ coefficient vector, $\boldsymbol{\varepsilon}-(\mathrm{nx} 1)$ random vector of residuals.

For the first hypothesis the multinomial version of the model is used. The dependent variable describing the type of the household is a qualitative variable with four categories coded as: 0 - only the respondent (resp. only), 1 - respondent and other people other than the partner (resp.+), 2 - respondent and his/her partner (couple), 3 - respondent with his/her partner and other people (couple+) as the reference category. The explanatory variable is health status (health) expressed as a dummy variable, with 0 - no problems in everyday life, and 1 - the occurrence of problems in everyday life (reference category) ${ }^{7}$. Control variables are: age (in years), sex $(0$ - male, 1 - female, reference category), the number of living children, educational

5 The Czech Republic (wave 2, $\mathrm{N}=2822$ ), France (wave $1, \mathrm{~N}=3116$ ), Hungary (wave 4 , $\mathrm{N}=3066$ ), Germany (wave $1, \mathrm{~N}=3003$ ), the Netherlands (wave $1, \mathrm{~N}=2961$ ), Poland (wave 2 , $\mathrm{N}=2455$ ), Portugal (wave 4, $\mathrm{N}=2061$ ), Slovenia (wave 4, $\mathrm{N}=2743$ ), Sweden (wave 1, $\mathrm{N}=3052$ ). For each country the data comes from the wave when the country contributed to the survey for the first time. Such a decision resulted from the fact that some countries did not refresh samples in the next waves. A detailed description of the source is available on the website of SHARE research, op. cit.

${ }^{6}$ The general form of the logit model was adopted from Stanisz 2007. A detailed model specification, considering the dependent variable under the category of the hidden variable, may be found in the work by Gruszczyński 2012.

${ }^{7}$ We only consider a presence of any difficulties in everyday life (one or more limitations with ADL or IALD) or its absence (no ADL limitations and no IADL limitations). The list of limitations has been presented in the previous section. 
level measured according to ISCED 97 (0 - at the most lower secondary, 1 - at least upper secondary education, reference category), subjective evaluation of economic situation of the household: 0 - bad or very bad, 1 - good or very good (reference category $)^{8}$.

In order to verify the second hypothesis the binomial logistic regression model is estimated ${ }^{9}$. In this case the binary dependent variable is defined as: 0 - no informal help from outside the household (reference category) and 1 indicates that some help is received. The following explanatory variables are used: the type of the household $(0-$ only the respondent, reference category, 1 - respondent and other people other than the partner, 2 - respondent and his/her partner, 3 - respondent with his/her partner and other people), age (in years), sex ( 0 - male, reference category, 1 - female); number of living children, educational level $(0-$ at the most lower secondary, reference category, 1 - at least upper secondary education), subjective evaluation of the economic situation of the household $(0 \text { - very bad, reference category, } 1 \text { - bad, } 2 \text { - good, } 3 \text { - very good })^{10}$.

\section{SOCIO-DEMOGRAPHIC CHARACTERISTICS OF OLDER PEOPLE IN THE SAMPLES}

In the beginning we present the structures of the elderly by the characteristics considered in the analysis. They include: health status ${ }^{11}$, receiving informal help by people with health problems, type of household, age, education, number of living children and subjective evaluation of the economic situation of the household.

The percentage of people experiencing (or not) problems in everyday life (health status) in selected European countries is presented in Table 1.

The lowest percentages of people with difficulties in everyday life are observed in Germany, the Netherlands and Sweden, and the highest in Poland, Hungary and Portugal. The Czech Republic, Slovenia and France occupy an intermediate position.

Table 2 presents the structure of elderly people experiencing difficulties with activities of daily living with regard to receiving the informal support from outside the household ${ }^{12}$.

The situation in the Czech Republic deserves our particular attention because of the exceptionally high percentage of people receiving informal aid from outside the

${ }^{8}$ Subjective evaluation of economic situation of household is based on an answer to the following question: "Thinking of your household's total monthly income, would you say that your household is able to make ends meet: (0) with great difficulty, (1) with some difficulty, (2) fairly easily or (3) easily". For the purpose of multinomial model, the answer (0) merged with (1) define bad or very bad situation. Answer (2) merged with (3) express good or very good situation.

${ }^{9}$ It is a special case of general logit model in which response variable $\mathrm{Y}$ has a binomial distribution.

${ }^{10}$ In this model an original coding of the answers has been adopted (see: footnote above).

11 A more detailed description of health status is presented in the previous section.

12 A more detailed description of informal help status is presented in the section "Purpose and scope of the research". 
Jolanta Kurkiewicz, Ewa Soja

Table 1. Health status - presence of difficulties with activities of daily living

\begin{tabular}{|c|c|c|}
\hline Countries & difficulties are absent & difficulties are present \\
\hline \multicolumn{3}{|c|}{ in percentage } \\
\hline \multicolumn{3}{|c|}{ Post-transitional Countries } \\
\hline Czech Rep. & 80.9 & 19.1 \\
\hline Hungary & 69.9 & 30.1 \\
\hline Poland & 66.8 & 33.2 \\
\hline Slovenia & 79.4 & 20.6 \\
\hline \multicolumn{3}{|c|}{ Northern, Western and Southern European Countries } \\
\hline France & 80.0 & 20.0 \\
\hline Germany & 83.9 & 16.1 \\
\hline Netherlands & 83.2 & 16.8 \\
\hline Portugal & 72.9 & 27.1 \\
\hline Sweden & 82.7 & 17.3 \\
\hline
\end{tabular}

Source: own elaboration on the basis of SHARE.

Table 2. Received help from outside the household for population with difficulties with activities of daily living

\begin{tabular}{|c|c|c|c|}
\hline Countries & help - yes & help - no & no data \\
\hline \multicolumn{4}{|c|}{ in percentage } \\
\hline \multicolumn{4}{|c|}{ Post-transitional Countries } \\
\hline Czech Rep. & 61.7 & 38.1 & 0.2 \\
\hline Hungary & 16.2 & 83.4 & 0.4 \\
\hline Poland & 16.2 & 83.4 & 0.4 \\
\hline Slovenia & 9.5 & 90.0 & 0.5 \\
\hline \multicolumn{4}{|c|}{ Northern, Western and Southern European Countries } \\
\hline France & 41.0 & 57.6 & 1.4 \\
\hline Germany & 38.8 & 60.2 & 1.2 \\
\hline Netherlands & 38.8 & 60.0 & 1.2 \\
\hline Portugal & 12.7 & 85.8 & 1.4 \\
\hline Sweden & 41.4 & 58.6 & 0.0 \\
\hline
\end{tabular}

Source: own elaboration on the basis of SHARE. 
Informal support for the elderly in the context of their living arrangements in selected...

household. Generally, the informal support in most countries of Northern, Western and Southern Europe is higher than in the post-transitional countries.

The age structure of older people regardless of the occurrence of problems in everyday life is demonstrated in Table 3 .

The common feature of the age structures of older people in Poland, the Czech Republic, Slovenia, France, the Netherlands and Sweden is the largest percentage of individuals aged 50-59. In the case of Hungary, Germany and Portugal the highest share of older people is observed for age 60-69. The percentage of population at age 70-79 is quite similar in all the investigated countries. Slovenia and France show a relatively high share of the oldest group $(80+)$.

Table 3. Structures of the populations by age

\begin{tabular}{|l|c|c|c|c|c|}
\hline \multicolumn{7}{|c|}{ Countries } & less than $50^{*}$ & $50-59$ & $60-69$ & $70-79$ & $80+$ \\
\hline \multicolumn{6}{|c|}{ in percentage } \\
\hline \multicolumn{7}{|c|}{ Post-transitional Countries } \\
\hline Czech Rep. & 3.4 & 37.4 & 32.0 & 18.8 & 8.3 \\
\hline Hungary & 2.6 & 33.8 & 35.6 & 20.0 & 8.1 \\
\hline Poland & 2.1 & 40.9 & 28.2 & 21.0 & 7.8 \\
\hline Slovenia & 1.7 & 35.2 & 30.3 & 22.2 & 10.6 \\
\hline \multicolumn{7}{|c|}{ Northern, Western and Southern European Countries } \\
\hline France & 5.0 & 38.1 & 25.3 & 21.1 & 10.5 \\
\hline Germany & 2.6 & 34.3 & 37.6 & 19.2 & 6.3 \\
\hline Netherlands & 4.6 & 40.5 & 29.5 & 18.0 & 7.5 \\
\hline Portugal & 3.4 & 32.3 & 36.0 & 19.7 & 8.7 \\
\hline Sweden & 2.3 & 35.3 & 31.9 & 20.8 & 9.7 \\
\hline
\end{tabular}

* Respondents taking part in SHARE research are people aged at least 50 and their partners who can be younger than 50 , which is the reason why the sample includes people under 50 years of age.

Source: own elaboration on the basis of SHARE.

The structure of the elderly by education level is varied (see Table 4).

The highest percentages of people with at least secondary education are observed in Germany, Hungary and Slovenia, and the lowest in Portugal. In the Czech Republic, France, the Netherlands, Portugal and Sweden the shares of population with at most lower secondary education are greater than in the better educated group.

Taking into account the number of living children (see Table 5) almost in all countries the elderly people possessing two living children are the most frequent category. The exceptions are Poland, France and Sweden where people with three and more children occur the most often. The highest share of people without children is observed in Germany and France. 
Jolanta Kurkiewicz, Ewa Soja

Table 4. Structures of the populations by education level

\begin{tabular}{|l|c|c|}
\hline \multicolumn{1}{|c|}{ Countries } & $\begin{array}{c}\text { education level - at most lower } \\
\text { secondary }\end{array}$ & $\begin{array}{c}\text { education level - at least upper } \\
\text { secondary }\end{array}$ \\
\hline \multicolumn{2}{|c|}{ in percentage } \\
\hline \multicolumn{2}{|c|}{ Post-transitional Countries } \\
\hline Czech Rep. & 57.3 & 42.7 \\
\hline Hungary & 31.4 & 68.6 \\
\hline Poland & 48.1 & 51.9 \\
\hline Slovenia & 34.8 & 65.2 \\
\hline \multicolumn{2}{|c|}{} & Northern, Western and Southern European Countries \\
\hline France & 54.7 & 45.3 \\
\hline Germany & 18.6 & 81.4 \\
\hline Netherlands & 58.0 & 42.0 \\
\hline Portugal & 65.3 & 34.7 \\
\hline Sweden & 53.3 & 46.7 \\
\hline
\end{tabular}

Source: own elaboration on the basis of SHARE.

Table 5. Structures of the populations by number of children alive

\begin{tabular}{|c|c|c|c|c|}
\hline Countries & 0 & 1 & 2 & $3+$ \\
\hline \multicolumn{5}{|c|}{ in percentage } \\
\hline \multicolumn{5}{|c|}{ Post-transitional Countries } \\
\hline Czech Rep. & 6.6 & 21.2 & 48.4 & 23.8 \\
\hline Hungary & 9.0 & 22.4 & 47.3 & 21.3 \\
\hline Poland & 6.7 & 11.5 & 38.0 & 43.8 \\
\hline Slovenia & 6.9 & 20.1 & 52.3 & 20.7 \\
\hline \multicolumn{5}{|c|}{ Northern, Western and Southern European Countries } \\
\hline France & 12.1 & 18.7 & 32.3 & 36.9 \\
\hline Germany & 14.5 & 24.6 & 35.4 & 25.5 \\
\hline Netherlands & 10.7 & 11.6 & 41.2 & 36.5 \\
\hline Portugal & 8.5 & 23.3 & 41.3 & 26.9 \\
\hline Sweden & 8.2 & 14.6 & 38.5 & 38.8 \\
\hline
\end{tabular}

Source: own elaboration on the basis of SHARE.

There are similarities and differences amongst regions of Europe as regards the type of household in which elderly people live (see Table 6).

A common characteristic for all countries is the highest share of people living only with a spouse or a partner. Poland could be treated as an exception with the largest group being the elderly living with a spouse and other people. 
Informal support for the elderly in the context of their living arrangements in selected...

Table 6. Structures of the populations by type of living arrangements

\begin{tabular}{|c|c|c|c|c|}
\hline Countries & only resp. & resp.+ & couple & couple+ \\
\hline \multicolumn{5}{|c|}{ in percentage } \\
\hline \multicolumn{5}{|c|}{ Post-transitional Countries } \\
\hline Czech Rep. & 23.1 & 6.4 & 51.6 & 18.9 \\
\hline Hungary & 18.0 & 9.4 & 46.8 & 25.7 \\
\hline Poland & 11.6 & 12.6 & 35.5 & 40.3 \\
\hline Slovenia & 18.0 & 7.9 & 45.4 & 28.8 \\
\hline \multicolumn{5}{|c|}{ Northern, Western and Southern European Countries } \\
\hline France & 23.1 & 5.9 & 48.4 & 22.7 \\
\hline Germany & 17.5 & 3.5 & 62.9 & 16.1 \\
\hline Netherlands & 16.6 & 2.0 & 63.5 & 17.9 \\
\hline Portugal & 11.7 & 9.4 & 47.9 & 30.9 \\
\hline Sweden & 20.4 & 2.1 & 65.9 & 11.5 \\
\hline
\end{tabular}

Source: own elaboration on the basis of SHARE.

A subjective evaluation of the economic situation of households ${ }^{13}$ varies between regions of Europe (see Table 7).

Table 7. Structures of the populations by subjective evaluation of economic situation of household

\begin{tabular}{|c|c|c|}
\hline Countries & $\begin{array}{l}\text { subjective evaluation - } \\
\text { bad or very bad }\end{array}$ & $\begin{array}{l}\text { subjective evaluation - } \\
\text { good or very good }\end{array}$ \\
\hline \multicolumn{3}{|c|}{ in percentage } \\
\hline \multicolumn{3}{|c|}{ Post-transitional Countries } \\
\hline Czech Rep. & 56.5 & 43.5 \\
\hline Hungary & 86.3 & 13.7 \\
\hline Poland & 75.6 & 24.4 \\
\hline Slovenia & 63.6 & 36.4 \\
\hline \multicolumn{3}{|c|}{ Northern, Western and Southern European Countries } \\
\hline France & 36.6 & 63.4 \\
\hline Germany & 27.4 & 72.6 \\
\hline Netherlands & 21.6 & 78.4 \\
\hline Portugal & 66.0 & 34.0 \\
\hline Sweden & 21.2 & 78.8 \\
\hline
\end{tabular}

Source: own elaboration on the basis of SHARE.

${ }^{13}$ A definition of subjective evaluation of the economic situation of households is included in the section "Empirical data and analysis method". 
In all post-transitional countries, the majority of the elderly people perceive their economic status as bad or very bad. As regards the countries of Northern and Western Europe, a vast majority of the elderly perceive their situation as good or very good. The opinion on economic condition of the elderly in Portugal is similar to post-transitional countries.

\section{THE IMPACT OF THE OCCURRENCE OF PROBLEMS WITH EVERYDAY LIFE ON LIVING ARRANGEMENTS OF THE ELDERLY}

Tables 8 and 9 present the results of the estimation of the multinomial logit model enabling the evaluation whether the probability of living in a given type of household depends on the occurrence of problems with everyday life, controlling for other variables. Models were estimated for each of the analyzed countries. Table 8 presents the results for post-transitional countries, while Table 9 shows the results for the countries of Northern, Western and Southern Europe.

The results of the multinomial logit model are interpreted with regard to the reference category of the dependent variable, i.e. the household inhabited by the respondent and his/her spouse/partner and other people (couple+).

For all post-transitional countries, health status does not affect the chance of living in the household type "resp. only" as compared with the reference household (couple+) with the other control variables constant. Age, sex and the number of living children turn out to be statistically significant for all countries. They influence in the same direction, i.e. the older the person is, the greater the chance to live alone (resp. only) as compared with living in the reference household (couple+), when controlling for the other variables. Men, as compared to women, have a lower chance to live on their own than in the reference household, ceteris paribus. Each subsequent child reduces the chance of living alone as compared with the reference household, ceteris paribus. In the case of Poland and Hungary, lower educational level increases the chance of living in a one-person household as compared with the household comprising a couple and other people (couple+), ceteris paribus. Additionally, in the Czech Republic the perception of the economic situation as bad increases the chance of living alone in comparison with the reference household, ceteris paribus.

Taking into account a household inhabited by the respondent and other people other than the respondent's partner (resp. + ), health status turns out to be statistically significant in all countries but the Czech Republic. A lack of problems with everyday life reduces the chance of living in a household of type "resp.+" as compared with the reference household, ceteris paribus. Age, sex and the number of living children are statistically significant, as in the case of living alone (resp. only). In the case of Hungary, lower education increases a risk of living in a household type "resp.+ " as compared with living in the reference household (couple+), ceteris paribus. Again, in the Czech Republic the subjective perception of the economic situation as bad 
Informal support for the elderly in the context of their living arrangements in selected...

Table 8. Results of multinomial logistic regression for the post-transitional Countries

\begin{tabular}{|c|c|c|c|c|c|}
\hline \multirow{2}{*}{ Type of living arrangements } & \multirow{2}{*}{ Variable } & Poland & Czech Rep. & Hungary & Slovenia \\
\hline & & \multicolumn{4}{|c|}{ Coefficient } \\
\hline \multirow{7}{*}{$\begin{array}{l}\text { living alone } \\
\text { (resp. only) }\end{array}$} & constant & -6.990 & -10.470 & -7.960 & -8.510 \\
\hline & $\operatorname{sex}$ & -0.450 & -0.670 & -0.680 & -0.560 \\
\hline & sub-econ & 0.020 & 0.240 & -0.090 & 0.090 \\
\hline & health & 0.040 & 0.060 & -0.090 & 0.060 \\
\hline & age & 0.110 & 0.190 & 0.130 & 0.140 \\
\hline & children & -0.540 & -0.580 & -0.500 & -0.560 \\
\hline & education & 0.170 & 0.000 & 0.210 & 0.110 \\
\hline \multirow{7}{*}{$\begin{array}{l}\text { single living with other } \\
\text { persons (resp.+) }\end{array}$} & constant & -6.390 & -7.980 & -6.110 & -6.290 \\
\hline & $\operatorname{sex}$ & -0.610 & -0.790 & -0.640 & -0.610 \\
\hline & sub-econ & 0.090 & 0.240 & 0.090 & -0.030 \\
\hline & health & -0.160 & -0.070 & -0.390 & -0.250 \\
\hline & age & 0.090 & 0.120 & 0.090 & 0.090 \\
\hline & children & -0.340 & -0.160 & $-\mathbf{0 . 3 3 0}$ & -0.430 \\
\hline & education & 0.140 & -0.040 & 0.270 & 0.150 \\
\hline \multirow{7}{*}{ couple only (couple) } & constant & -3.930 & -5.870 & -3.860 & -4.720 \\
\hline & $\operatorname{sex}$ & -0.060 & -0.120 & -0.110 & -0.150 \\
\hline & sub-econ & -0.120 & -0.070 & -0.220 & -0.140 \\
\hline & health & -0.150 & 0.090 & -0.160 & 0.010 \\
\hline & age & 0.080 & 0.120 & 0.090 & 0.100 \\
\hline & children & -0.370 & -0.250 & -0.290 & -0.420 \\
\hline & education & -0.010 & 0.090 & 0.020 & -0.040 \\
\hline \multicolumn{2}{|c|}{ Goodness of fit: deviance (Stat/Df) } & 0.772 & 0.695 & 0.761 & 0.767 \\
\hline
\end{tabular}

Source: own elaboration on the basis of SHARE.

Bold - variable is significant $(\mathrm{p}<0.05)$

Ref. category for dependent variable: $($ couple +$)$

Ref. category: sex - female, sub-econ - good or very good, health - difficulties are present, education - at least upper secondary 
increases the chance of living with another person other than a partner (resp.+) as compared with living in the reference household, with the other variables controlled.

In the case of households inhabited by couples (couple), health status is statistically significant only for Poland and Hungary. People without problems in everyday life have lower chances of living only with a partner (couple) as compared with living in the household of type "couple+", with the other variables controlled. Age, sex, the number of living children and subjective perception of the economic situation affect the living arrangement in almost all countries. The direction of impact is the same as in previous types of households. There are two exceptions - the variable sex is insignificant for Poland and subjective perception of the economic situation for the Czech Republic.

In Northern, Western and Southern countries, in the case of the household type "resp. only" the influence of variables: health status, age, sex and number of living children is similar to post-transitional countries (see Table 9). The education affects the chance of living in the household type "resp. only" only in the case of the Netherlands and Portugal. As regards the Netherlands, lower education increases the chance of living alone, while the opposite is true in the case of Portugal: lower education reduces the chance of living alone as compared with living in a household comprising a couple and other people, ceteris paribus. Additionally, in Germany and in the Netherlands the perception of the economic situation as bad increases the chance of living alone as compared with living in the reference household, with the other variables controlled.

The results obtained for the households of type "resp.+" demonstrate that health status is statistically significant only for France and Germany where people without problems in everyday life have a smaller chance of living in a household type "resp.+" as compared with living in the reference household, ceteris paribus. In all countries, the older the person is the greater the chance to live in the household type "resp. +". Except for France, the subjective perception of the economic situation as bad increases the chance of living with another person other than a partner (resp. + ) as compared to the reference household, with the other variables controlled. Except for the Netherlands, men have a smaller chance than women to live with any other person other than a partner (resp.+). Additionally, in the case of Germany lower education level increases a risk of living in a household type "resp. +" as compared with living in the reference household (couple+), ceteris paribus.

Considering households in which couples live alone (type couple), health status is significant only for the Netherlands. People without problems in everyday life have a greater chance of living only with a partner (couple) as compared to the reference category (couple + ), ceteris paribus. Age, sex and the number of living children are significant for almost all countries. The directions of their influence are identical to the described above. Two exceptions are observed. The variable sex is insignificant for the Netherlands and Portugal. Additionally, in France and Sweden the economic situation evaluated as bad reduces the chance of living only with a partner as compared with the reference category (couple+), ceteris paribus. 
Informal support for the elderly in the context of their living arrangements in selected...

Table 9. Results of multinomial logistic regression for the Northern, Western and Southern European Countries

\begin{tabular}{|c|c|c|c|c|c|c|}
\hline \multirow{2}{*}{$\begin{array}{l}\text { Type of living } \\
\text { arrangements }\end{array}$} & \multirow{2}{*}{ Variable } & France & Sweden & Germany & Netherlands & Portugal \\
\hline & & \multicolumn{5}{|c|}{ Coefficient } \\
\hline \multirow{7}{*}{$\begin{array}{l}\text { living alone } \\
\text { (resp. only) }\end{array}$} & constant & -11.410 & -12.400 & -9.450 & -12.120 & -7.670 \\
\hline & sex & -0.660 & -0.520 & -0.570 & -0.510 & -0.530 \\
\hline & sub-econ & -0.060 & 0.070 & 0.250 & 0.510 & 0.180 \\
\hline & health & -0.110 & -0.220 & -0.160 & 0.130 & 0.070 \\
\hline & age & 0.200 & 0.240 & 0.170 & 0.250 & 0.110 \\
\hline & children & -0.310 & -0.650 & -0.590 & -0.680 & -0.380 \\
\hline & education & -0.110 & -0.030 & -0.070 & 0.340 & -0.240 \\
\hline \multirow{7}{*}{$\begin{array}{l}\text { single living with other } \\
\text { persons (resp. }+ \text { ) }\end{array}$} & constant & -9.270 & -8.420 & -9.150 & -10.880 & -8.190 \\
\hline & sex & -0.800 & -0.690 & -0.940 & -0.340 & -0.800 \\
\hline & sub-econ & 0.080 & 0.350 & 0.490 & 0.780 & 0.310 \\
\hline & health & -0.360 & -0.130 & -0.410 & 0.210 & 0.050 \\
\hline & age & 0.140 & 0.130 & 0.140 & 0.170 & 0.110 \\
\hline & children & -0.240 & -0.280 & -0.480 & -0.220 & -0.100 \\
\hline & education & 0.090 & -0.140 & 0.280 & 0.310 & -0.190 \\
\hline \multirow{7}{*}{ couple only (couple) } & constant & -7.910 & -9.370 & -5.620 & -8.470 & -3.770 \\
\hline & $\operatorname{sex}$ & -0.170 & -0.220 & -0.210 & -0.170 & -0.060 \\
\hline & sub-econ & -0.320 & -0.530 & -0.040 & 0.030 & 0.020 \\
\hline & health & 0.100 & 0.020 & -0.080 & 0.300 & 0.100 \\
\hline & age & 0.150 & 0.200 & 0.130 & 0.190 & 0.080 \\
\hline & children & -0.230 & -0.340 & -0.420 & -0.350 & -0.250 \\
\hline & education & -0.030 & -0.040 & -0.110 & 0.250 & -0.110 \\
\hline \multicolumn{2}{|c|}{ Goodness of fit: deviance (Stat/Df) } & 0.678 & 0.526 & 0.588 & 0.564 & 0.723 \\
\hline
\end{tabular}

Source: own elaboration on the basis of SHARE.

Bold - variable is significant $(\mathrm{p}<0.05)$

Ref. category for dependent variable: $($ couple + )

Ref. category: sex - female, sub-econ - good or very good, health - difficulties are present, education - at least upper secondary 
In order to compare the results obtained for both groups of the countries, the odds ratios for significant variables are used (see Table 10).

In post-transitional countries a lack of problems with everyday life (variable health in the models) reduces the chance of living in a household type "resp.+" and "couple" as compared with living in the reference household (couple+) more frequently than in the region of Northern, Western and Southern Europe. Generally, there is a greater decrease in this chance in the countries of Northern, Western and Southern Europe.

Table 10. Percentage decrease/increase of the chance to live in a household of a given type as compared with the reference household type.

\begin{tabular}{|c|c|c|c|c|c|c|c|c|c|c|}
\hline $\begin{array}{l}\frac{0}{0} \\
\frac{\pi}{\pi} \\
\frac{\pi}{D}\end{array}$ & 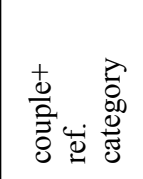 & $\begin{array}{l}\vec{E} \\
\frac{\vec{t}}{0} \\
2\end{array}$ & 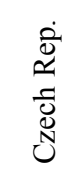 & 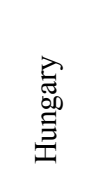 & $\begin{array}{l}\frac{\pi}{0} \\
\frac{0}{0} \\
\frac{0}{\infty}\end{array}$ & 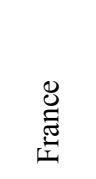 & 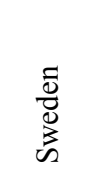 & $\begin{array}{l}\vec{\Xi} \\
\text { है } \\
0\end{array}$ & 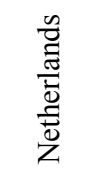 & 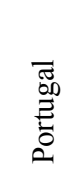 \\
\hline \multirow{3}{*}{ শ্ } & resp. only & -36.3 & -48.8 & -49.2 & -42.7 & -48.5 & -40.5 & -43.7 & -40.0 & -41.0 \\
\hline & resp.+ & -45.7 & -54.4 & -47.4 & -45.5 & -55.0 & -49.6 & -60.8 & & -55.3 \\
\hline & couple & & -11.0 & -10.2 & -13.8 & -15.5 & -20.0 & -19.0 & & \\
\hline \multirow{3}{*}{ 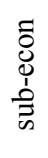 } & resp. only & & 26.8 & & & & & 28.9 & 67.3 & \\
\hline & resp.+ & & 26.8 & & & & 41.4 & 63.2 & 118.5 & 36.7 \\
\hline & couple & -11.5 & & -19.5 & -13.5 & -27.4 & -41.4 & & & \\
\hline \multirow{3}{*}{ 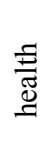 } & resp. only & & & & & & & & & \\
\hline & resp.+ & -14.9 & & -32.5 & -21.8 & -30.2 & & -33.3 & & \\
\hline & couple & -13.7 & & -15.1 & & & & & 34.7 & \\
\hline \multirow{3}{*}{ 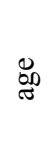 } & resp. only & 11.6 & 20.5 & 14.4 & 14.9 & 21.8 & 27.3 & 19.0 & 28.6 & 12.1 \\
\hline & resp.+ & 9.9 & 12.5 & 9.7 & 9.9 & 15.4 & 14.0 & 15.5 & 19.0 & 11.3 \\
\hline & couple & 8.1 & 13.1 & 9.0 & 10.1 & 16.5 & 21.9 & 13.8 & 21.0 & 7.8 \\
\hline \multirow{3}{*}{$\begin{array}{l}\frac{7}{0} \\
\frac{7}{0} \\
\frac{7}{0}\end{array}$} & resp. only & -41.6 & -43.9 & -39.6 & -42.6 & -26.4 & -47.6 & -44.6 & -49.2 & -31.5 \\
\hline & resp.+ & -28.8 & -15.2 & -27.9 & -35.3 & -21.4 & -24.2 & -38.2 & & \\
\hline & couple & -31.2 & -22.2 & -24.9 & -34.5 & -20.5 & -28.6 & -34.1 & -29.7 & -21.7 \\
\hline \multirow{3}{*}{ 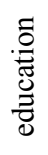 } & resp. only & 18.3 & & 23.1 & & & & & 40.6 & -21.0 \\
\hline & resp.+ & & & 31.0 & & & & 31.8 & & \\
\hline & couple & & & & & & & & & \\
\hline
\end{tabular}

Source: own elaboration on the basis of SHARE.

Ref. category: sex - female, sub-econ - good or very good, health - difficulties are present, education - at least upper secondary 
In all countries, the older the person is the greater the chance of living in the examined types of households in comparison to the reference category (household composed of couple and other people). In Northern, Western and Southern European countries (except for Portugal) the changes of chances are greater than amongst the post-transitional countries.

Each subsequent child reduces the chance of living alone as compared with the reference household (couple), ceteris paribus. This regularity is observed in all considered countries and for each type of household (resp. only, resp. + , couple), except for the Netherlands and Portugal for the households of type "couple". Decreases in chances are similar in both groups of the countries. Men have a smaller chance than women to live in all considered types of households (resp. only, resp.+, couple) as compared to the reference category (couple + ). This relation occurs in most countries. The exception are: Poland (for couple), the Netherlands (for resp.+ and couple) and Portugal (for couple). The decreases of chances are greater for living alone (resp. only) or with another person other than a partner (resp. ${ }^{+}$) than for living in households of type "couple".

The subjective perception of the economic situation as bad increases the chance of living alone (resp. only) or with another person other than a partner (resp.+) as compared with living in a household of type "couple+" more often in the countries of Northern, Western and Southern Europe than in the post-transitional countries. The changes of the chances are also higher in the regions of Northern, Western and Southern Europe.

The perception of the economic situation of the household as bad reduces the chance of living in a household of type couple as compared with the reference household (couple+). In this case this regularity occurs more frequently in the post-transitional countries.

Education has a significant impact on the chance of living in the household of a given type only in some countries. In most cases lower education increases the chance of living alone or with another person other than a partner.

\section{INFORMAL SUPPORT FOR THE ELDERLY EXPERIENCING PROBLEMS IN EVERYDAY LIFE}

The results of the binomial logistic regression for the post-transitional countries and Northern, Western and Southern European countries are presented in Tables 11 and 12, respectively. Models are estimated separately for each country and all of them are significant. The analysis concerns only people experiencing health problems (i.e. people experiencing difficulties in everyday life).

In all countries there are only two variables, i.e. household type and age, that significantly affect the probability of receiving informal help from outside the household (except for the age variable for Portugal). In the case of persons who do not live 
Table 11. Determinants of receiving help from outside the household - binomial logistic regression for the Post-transitional Countries

\begin{tabular}{|l|c|c|c|c|}
\hline \multirow{2}{*}{ Variable } & Poland & Czech Rep. & Hungary & Slovenia \\
\cline { 2 - 5 } & \multicolumn{4}{|c|}{ coefficient } \\
\hline constant & $\mathbf{- 1 . 8 2 4}$ & $\mathbf{- 1 . 6 9 3}$ & $\mathbf{- 2 . 6 1 4}$ & $\mathbf{- 4 . 1 2 0}$ \\
\hline sex & -0.026 & -0.133 & -0.040 & 0.039 \\
\hline sub-econ. & -0.072 & 0.007 & 0.023 & 0.007 \\
\hline typehh & $\mathbf{- 0 . 2 1 3}$ & $\mathbf{- 0 . 4 7 0}$ & $\mathbf{- 0 . 5 0 1}$ & $\mathbf{- 0 . 5 6 9}$ \\
\hline age & $\mathbf{0 . 0 2 7}$ & $\mathbf{0 . 0 3 8}$ & $\mathbf{0 . 0 4 3}$ & $\mathbf{0 . 0 3 8}$ \\
\hline children & -0.079 & 0.156 & 0.041 & 0.158 \\
\hline education & -0.072 & -0.028 & -0.087 & 0.173 \\
\hline & \multicolumn{5}{|c|}{ Likelihood Ratio Test } \\
\hline Chi-square & 34.490 & 66.460 & 96.810 & 65.760 \\
\hline p-value & 0.000 & 0.000 & 0.000 & 0.000 \\
\hline
\end{tabular}

Source: own elaboration on the basis of SHARE.

Bold - variable is significant $(\mathrm{p}<0.05)$,

Ref. category for dependent variable: help - absence of aid

Ref. category for descriptive variables: sex - male, sub-econ - very bad,

typehh (type of the household) - resp. only, education - at most lower secondary

Table 12. Determinants of receiving help from outside the household - binomial logistic regression for the Northern, Western and Southern European Countries

\begin{tabular}{|l|r|r|r|r|r|}
\hline \multirow{2}{*}{ Variable } & France & Sweden & Germany & Netherlands & Portugal \\
\cline { 2 - 6 } & \multicolumn{5}{|c|}{ coefficient } \\
\hline constant & -3.050 & $\mathbf{- 2 . 3 6 9}$ & -0.847 & -1.464 & -0.141 \\
\hline sex & 0.292 & 0.137 & -0.223 & 0.314 & -0.323 \\
\hline sub-econ. & -0.022 & 0.033 & 0.025 & -0.026 & -0.022 \\
\hline typehh & -0.363 & -0.617 & -0.297 & -0.638 & -0.629 \\
\hline age & $\mathbf{0 . 0 3 9}$ & $\mathbf{0 . 0 3 3}$ & $\mathbf{0 . 0 2 0}$ & $\mathbf{0 . 0 2 1}$ & 0.005 \\
\hline children & $\mathbf{0 . 1 1 4}$ & $\mathbf{0 . 1 4 9}$ & -0.035 & 0.079 & 0.017 \\
\hline education & $\mathbf{- 0 . 5 0 8}$ & -0.389 & -0.033 & $\mathbf{0 . 4 7 0}$ & -0.209 \\
\hline & & Likelihood Ratio Test & \\
\hline Chi-square & 90.910 & 89.750 & 20.760 & 74.000 & 39.230 \\
\hline p-value & 0.000 & 0.000 & 0.002 & 0.000 & 0.000 \\
\hline
\end{tabular}

Source: own elaboration on the basis of SHARE.

Bold - variable is significant $(\mathrm{p}<0.05)$,

Ref. category for dependent variable: help - absence of aid

Ref. category for descriptive variables: sex - male, sub-econ - very bad,

typehh (type of the household) - resp. only, education - at most lower secondary 
on their own there is a lower probability of receiving informal aid from outside their household than in the case of elderly people living alone. The probability of obtaining aid from outside increases with age. Additionally, the number of living children is significant for France and Sweden and education for the Netherlands and France.

Table 13 contains the changes of the odds ratios describing the possibility of receiving informal support from outside the household by living arrangements and age of people with difficulties in everyday life.

Table 13. Increase/decrease of the chance to receive help from outside the household by significant variables (in \%)

\begin{tabular}{|c|c|c|c|c|}
\hline \multirow{2}{*}{ Countries } & \multicolumn{3}{|c|}{$\begin{array}{l}\text { Household type ref. category resp. } \\
\text { only }\end{array}$} & \multirow{2}{*}{$\begin{array}{l}\text { Age } \\
1 \text { year }\end{array}$} \\
\hline & resp + & couple & couple + & \\
\hline \multicolumn{5}{|c|}{ Post-transitional Countries } \\
\hline Czech Rep. & -37.48 & -60.91 & -75.56 & 3.89 \\
\hline Hungary & -39.40 & -63.27 & -77.74 & 3.58 \\
\hline Poland & -19.21 & -34.73 & -47.27 & 2.72 \\
\hline Slovenia & -43.38 & -67.94 & -81.85 & 4.40 \\
\hline \multicolumn{5}{|c|}{ Northern, Western and Southern European Countries } \\
\hline France & -30.40 & -51.60 & -66.30 & 4.00 \\
\hline Germany & -25.67 & -44.75 & -58.93 & 2.03 \\
\hline Netherlands & -47.17 & -72.09 & -85.26 & 2.15 \\
\hline Portugal & -46.71 & -71.60 & -84.87 & \\
\hline Sweden & -46.03 & -70.87 & -84.28 & 3.36 \\
\hline
\end{tabular}

Source: own elaboration on the basis of SHARE.

There is the greatest decrease of chances of receiving informal help for elderly people living with a partner and other people (couple+) as compared with the household in which elderly people live on their own (only resp.) while the lowest decrease is observed for households of type "resp.+".

From the considered countries, Poland deserves our particular attention because of the lowest decrease of the chance of receiving the aid for all types of households as compared with households in which people live alone (resp. only). The greatest decreases of chances are observed for the Netherlands, Portugal and Sweden. Generally, in post-transitional countries, the impact of age is slightly greater than in the countries of Northern, Western and Southern Europe. 


\section{CONCLUSIONS}

In our concluding remarks, we concentrate on the results directly associated with our research hypotheses. The main goal of the paper was to investigate the informal support for the elderly experiencing difficulties in everyday life connected with health. The multinomial logit model has been used in order to verify the hypothesis that this kind of problems determines the living arrangement of the elderly. The households composed of a couple at old age living with their children, other relatives and non-relatives, have been chosen as the reference category. At every step of the analysis, the changes of chances were compared to this category.

1. As for the households composed of the elderly (single or couple at old age) the analysis reveals the following regularities:

a) With regard to the one-person households, in the post-transitional countries it has been found that the difficulties in everyday life do not affect the chance of living independently. As regards households composed of an elderly couple alone, it has been observed that the variable describing health status has a significant effect in the cases of Poland and Hungary. In these countries people with everyday life difficulties have greater chance of living only with a partner.

b) In the case of Northern, Western and Southern countries (similarly to posttransitional countries), health status does not affect the chance of living as a single. Only in the Netherlands people experiencing everyday life difficulties have a smaller chance of living only with a partner.

2. Regarding single older persons sharing their households with other people (children, relatives or non-relatives) the models for Poland, Hungary, Slovenia, France and Germany demonstrate that a presence of difficulties experienced in everyday life increases the chance of living in this type of household.

3. The changes in the chance of living in the households of an elderly person without a partner, living with other people, or composed of a couple at old age only, are greater in Northern, Western and Southern Europe than in the post-transitional countries.

Besides the variable describing the ability to function in everyday life (health status), other features such as age, sex, education level, and economic situation (subjective evaluation) have been introduced to the multinomial model. Their impact on living arrangement of the elderly is presented in detail in the previous sections of the paper.

The binomial regression model has been used in order to answer a question if informal support from outside the household obtained by the people experiencing problems in everyday life is determined by the type of the household and by social and demographic characteristics of the individuals receiving the support. In this case, the dependent binary variable is receiving or not receiving support from outside the household. The type of the household presented above is introduced as one of the explanatory variables. Additional variables describe demographic characteristics (age, 
sex, number of living children), social status (level of education) and subjective evaluation of the economic situation.

1. Two variables (household type and age) significantly affect the probability of receiving the informal support from outside the household in all considered countries (except for Portugal in the case of age). The elderly sharing the household with other persons have a lower probability of receiving informal aid than the ones living alone. The probability of obtaining aid from outside increases with age.

2. There are some models where additional variables have a significant effect, namely number of living children for France and Sweden and education level for France and Netherlands.

3. The decrease in the chance of receiving informal support is the greatest for elderly people living with a partner and other persons as compared with the household in which elderly people live on their own.

4. The lowest decrease in the chance of receiving informal support is observed for households composed of an elderly person without a partner, living with other people.

5. The lowest decrease of the chance to receive informal support, compared to households of single older person, has been observed in Poland for all types of households.

Summing up the achieved results in the context of the hypotheses being verified, we may state that the occurrence of difficulties in everyday life does not affect the chance of living in a one-person household. For the other types of households the aforementioned influence turns out to be significant only for selected countries. In particular, the influence is observed most often in post-transitional countries. In all investigated countries, for people experiencing difficulties in everyday life, a significant influence of the type of a household on receiving help from outside the household has been observed. It is worth emphasizing that, in general, the formulated hypotheses have been verified. In future research, a closer attention should be paid to elderly people living alone and to incorporating various types of limitations in everyday life separately for men and women. In order to better explain the differences between post-transitional and other European countries the formal and institutional supports should be introduced.

\section{REFERENCES}

Abramowska-Kmon A., 2011, Zmiany modelu rodziny a zapotrzebowanie na uslugi opiekuńcze dla osób starszych, rozprawa doktorska, SGH, Warszawa (maszynopis).

Bengtson V.L., Rosenthal C.J., Burton L.M., 1990, Families and ageing: Diversity and heterogeneity, [in:] R.H. Binstock, L.K. George (eds.), Handbook of Aging and the Social Sciences, 3rd ed., Academic Press, New York, pp. 263-287.

Börsch-Supan A., 2003, Labor market effects of population aging, „Review of Labour Economics and Industrial Relations", vol. 17, pp. 5-44. 
Chłoń-Domińczak A. (eds.), 2014, Portret generacji 50+ w Polsce i w Europie. Wyniki badania zdrowia, starzenia się i przechodzenia na emeryturę (SHARE), Instytut Badań Edukacyjnych, http://www. researchgate.net/publication/ (dostęp 23.04.2015)

de Jong Gierveld J., de Valk H., Blommesteijn M., 2001, Living arrangements of older persons and family support in more developed countries, [in:] United Nations, Population Ageing and Living Arrangements of Older Persons: Critical Issues and Policy Responses, United Nations Population Bulletin, Special Issue No. 42/43.

de Jong Gierveld J., Dykstra P.A., Schenk N., 2012, Living arrangements, intergenerational support types and older adult loneliness in Eastern and Western Europe, "Demographic Research", Special Collection, vol. 27(7).

Dykstra P.A., Komter A.E., 2012, Generational interdependencies in families: The MULTILINKS research programme, „Demographic Research”, 27, 487-506.

Dykstra P.A, van den Broek T., Muresan C., Haragus M., Haragus P-T., Abramowska-Kmon A., Kotowska I.E., 2013, State-of-the-art report Intergenerational linkages in families, Families and Societies, Changing families and sustainable societies: Policy contexts and diversity over the life course and across generations, Working Paper Series, no. 1, A project funded by European Union's Seventh Framework Programme.

Grotowska-Leder J., 2008, Wsparcie spoleczne w perspektywie teorii socjologicznych, [w:] J. GrotowskaLeder (red.), Sieci wsparcia społecznego jako przejaw integracji i dezintegracji społecznej, Wydawnictwo Uniwersytetu Łódzkiego, Łódź.

Grundy E., 2001, Living arrangements and the health of older persons in developed countries, [in:] United Nations, Population Ageing and Living Arrangements of Older Persons: Critical Issues and Policy Responses, United Nations Population Bulletin, Special Issue No. 42/43.

Gruszczyński M., 2012, Mikroekonometria. Modele i metody analizy danych indywidualnych. Oficyna, Warszawa, pp. 185-196.

United Nations, 2005, Informal support transfers between generations, [in:] United Nations, Living Arrangements of Older People Around the World, http://www.un.org/en/development/desa/ population/publications/ageing/living-arrangements.shtml (access 15.04.2014).

Kalbarczyk M., Nicińska A., 2009, Finansowe i niefinansowe transfery w próbie SHARE, „Polityka Społeczna" no. 4, pp.13-18.

Knipscheer C.P.M., 1992, Interdependency among the generations within the family: A sociological approach, [in:] H. Bouma, J.A.M. Graafmans, (eds.), Gerontechnology, IOS Press, Amsterdam, pp. $39-50$.

Lee R., Tuljapurkar Sh., 1997, Death and taxes: How longer life will affect social security, „Demography”, 34: $67-81$.

Lesthaeghe R., 2010, The unfolding story of the Second Demographic Transition, „Population and Development Review", 36 (2): 211-251.

Martin, L., Culter, S., 1983, Mortality decline and Japanese family structure. „Population and Development Review", 9 (4), pp. 633-649.

Palloni A., 2001, Living arrangements of older persons, [in:] United Nations, Population ageing and living arrangements of older persons: Critical issues and policy responses, United Nations Population Bulletin, Special Issue No. 42/43.

Prskawetz A., Fent T., Guest R., 2008, Workforce aging and labor productivity: The role of supply and demand for labor in G7 countries, „Population and Development and Review”, vol. 34, pp. 298-323.

Puur A., Sakkeus L., Põldma A., Herm A., 2011, Intergenerational family constellations in contemporary Europe: Evidence from the Generations and Gender Survey, „Demographic Research”, vol. 25, pp. $135-172$.

Saraceno C., Keck W., 2008, The institutional framework of intergenerational family obligations in Europe: A conceptual and methodological overview, Wissenschaftszentrum Berlin für Sozialforschung, November 2008. 
Informal support for the elderly in the context of their living arrangements in selected...

Soja E., Stonawski M., 2012, Starzenie się populacji a poziom życia ludności, [w]: J. Kurkiewicz (red.)

Demograficzne uwarunkowania i wybrane społeczno-ekonomiczne konsekwencje starzenia się ludności w krajach europejskich, Wydawnictwo Uniwersytetu Ekonomicznego w Krakowie, Kraków.

Stanisz A., 2007, Przystępny kurs statystyki. Tom 2. Modele liniowe i nieliniowe. StatSoft, Kraków.

Uhlenberg P., 1993, Demographic change and kin relationships in later life, „Annual Review of Gerontology and Geriatrics", vol. 13, pp. 219-238.

van de Kaa D.J., 1987, Europe's second demographic transition. „Population Bulletin” 42 (1), Population Reference Bureau Inc, Washington.

van de Kaa D.J., 2004, Is the second demographic transition a useful research concept? Questions and answers. „Vienna Yearbook of Population Research” 2004: 4-10.

\title{
INFORMAL SUPPORT FOR THE ELDERLY IN THE CONTEXT OF THEIR LIVING ARRANGEMENTS IN SELECTED EUROPEAN COUNTRIES
}

\begin{abstract}
The main objective of this paper is to analyze the informal support for the elderly experiencing problems in everyday life connected with physical, mental or emotional fitness. The analysis covers groups of countries chosen from the participants of SHARE project. The multinomial logit model has been used in order to verify the hypothesis that such problems determine the living arrangements of the elderly. The binomial regression model has been used in order to answer a question if informal support from outside the household obtained by the people experiencing problems in everyday life is determined by the type of the household and by social and demographic characteristics of the individuals receiving the support. In conclusion we state that the occurrence of difficulties in everyday life does not affect the chance of living in a one-person household. For the other types of the households the aforementioned influence turns out to be significant only for selected countries. In all investigated countries, for people experiencing difficulties in everyday life, a significant influence of the type of the household on receiving help from outside the household has been observed. In future research, a closer attention should be paid to elderly people living alone and to incorporating various types of limitations in everyday life separately for men and women. For better explanation of the differences between post-transitional and the other European countries the formal and institutional supports should be introduced.
\end{abstract}

Keywords: support for the elderly, difficulties of everyday life, living arrangements of the elderly, logit models 